\title{
Releasing primary dormancy in Avena fatua L. caryopses by smoke-derived butenolide
}

\author{
Jan Kępczyński • Danuta Cembrowska • \\ Johannes Van Staden
}

Received: 11 December 2009/Accepted: 4 June 2010/Published online: 22 June 2010

(C) The Author(s) 2010. This article is published with open access at Springerlink.com

\begin{abstract}
The effect of smoke and smoke-derived butenolide in releasing dormancy of caryopses (referred to as seeds) of the economically important weed Avena fatua $\mathrm{L}$. was studied. Seeds of A. fatua are dormant after harvest. Both smoke-water and butenolide, applied continuously, removed dormancy in darkness at 15,20 and $25^{\circ} \mathrm{C}$ and slightly at $30^{\circ} \mathrm{C}$. Butenolide was very active at a concentration of $10^{-8}$ $\mathrm{M}$. Butenolide at $10^{-8} \mathrm{M}$ was also able to remove dormancy at $20^{\circ} \mathrm{C}$ when applied for 12 or $24 \mathrm{~h}$ at $4{ }^{\circ} \mathrm{C}$ or for 3 to $24 \mathrm{~h}$ at $20^{\circ} \mathrm{C}$. Sensitivity to butenolide decreased with longer preincubation times in water. This compound was less effective in releasing dormancy in the light than in darkness. Dormancy release by butenolide involves induction of cell-cycle activity just before coleorhiza protrusion. Stimulatory effects of smoke-water and butenolide were also observed in respect of seedling growth and vigor.
\end{abstract}

Keywords Avena fatua - Butenolide - Caryopses · Seeds $\cdot$ Smoke $\cdot$ Germination $\cdot$ Primary dormancy

\section{Introduction}

Avena fatua $\mathrm{L}$. is an important and widespread weed in the world. It is a persistent weed with a combination of

J. Kępczyński ( $\square) \cdot$ D. Cembrowska

Department of Plant Physiology, University of Szczecin,

Wąska 13, 71-415 Szczecin, Poland

e-mail: jankepcz@wp.pl

J. Van Staden

Research Centre for Plant Growth and Development,

School of Biological and Conservation Sciences,

University of KwaZulu-Natal Pietermaritzburg,

Private Bag X01, Scottsville 3209, South Africa dormancy and seed longevity which allow viable seeds to infest agricultural soils for several years (Naylor 1983). Seeds of some lines of A. fatua are dormant and others nondormant (Adkins et al. 1986). Dormancy can be associated with the testa, pericarp and/or embryo (Adkins and Peters 2001). The temperature optimum for germination of nonafter-ripened dormant seeds is $4-12^{\circ} \mathrm{C}$, with little germination occurring between 20 and $24^{\circ} \mathrm{C}$. Non-dormant seeds germinated over a wide temperature range of $4-24^{\circ} \mathrm{C}$ (Naylor and Fedec 1978). Various physical and chemical factors can affect the dormancy state of A. fatua seeds. Dormancy in these seeds can be released by dry storage at temperatures from 25 to $40^{\circ} \mathrm{C}$ (Foley 1994). Light promoted the germination of partially dormant seeds but had no effect on fully dormant seeds (Hilton and Bitterli 1983). Primary dormancy may also be alleviated by gibberellic acid (Adkins et al. 1986). Ethephon did not affect germination of freshly harvested A. fatua seeds but stimulated germination of partially after-ripened seeds (Adkins and Ross 1981). Avena fatua seeds have been used in many studies as a model to study dormancy in order to better understand the dormancy state of grass seeds and to develop new strategies of weed control in the soil seed bank.

Smoke derived from burning plant material and smokewater, obtained by bubbling smoke through water effectively stimulates the germination of seeds of many plant species from fire-prone areas of South Africa, Australia and California and also from fire-free environments including arable weeds and crop plants such as lettuce, celery and red rice (Brown 1993; Brown and Van Staden 1997; De Lange and Boucher 1990; Light et al. 2009). Smoke applied to seeds also markedly improves seedling growth of both fire-sensitive and non-fire-sensitive seeds. Although the role of smoke in releasing dormancy, germination and seedling growth has been studied since 1990 it was only in 2004 that a 
germination-active compound, a butenolide, was identified from plant-derived smoke (Van Staden et al. 2004) and burned cellulose (Flematti et al. 2004). The discovery of this butenolide created the possibility of studying the physiological roles of new natural compounds and allowing a better understanding of the role of smoke in releasing dormancy and seed germination from soils. Seeds responding to smoke are usually also sensitive to the butenolide. In comparison to smoke, the butenolide was found to stimulate a broader range of weed species (Daws et al. 2007). This is comprehensible since smoke contains several thousand compounds (Maga 1988) some of which may inhibit germination. Both smoke and butenolide can enhance seedling growth of arable weed species (Daws et al. 2007) and improve seedling vigor of Oryza sativa and Dioscorea dregeana (Kulkarni et al. 2006, 2007). Likewise, both smoke and butenolide enhanced seedling growth of crop plants such as tomato, bean, okra and maize (Van Staden et al. 2006).

The commercially available smoke-water "Seed Starter" stimulated germination of A. fatua (Adkins and Peters 2001). Smoke-water only slightly removed dormancy of the seeds at harvest. It had a greater capacity to overcome dormancy in partly after-ripened than in freshly harvested seeds. Stevens et al. (2007) observed that both smoke-water and butenolide stimulated germination of freshly harvested but only partially that of dormant seeds of A. fatua from Australia. In another study, smoke-water inhibited germination but butenolide only partially stimulated germination of dry stored A. fatua seeds collected in the United Kingdom (Daws et al. 2007).

The aim of the present study was to examine the importance of butenolide in releasing deep dormancy in A. fatua seeds collected in Poland. To achieve this aim, smoke containing butenolide and pure butenolide were applied continuously during incubation at various temperatures. Butenolide was also used during different periods of imbibition at 4 or $20^{\circ} \mathrm{C}$ and after different times of imbibition in water. The sensitivity of seeds to smoke water and butenolide was compared in darkness, constant and alternating light. Since breaking dormancy in seeds may induce an increase in nuclear DNA replication in the radicle tip (Groot et al. 1997) the effect of butenolide on cell-cycle activity in cells before coleorhiza protrusion was determined using flow cytometry. Effect of smoke and butenolide on seedling vigor was also recorded.

\section{Materials and methods}

Plant material

Avena fatua caryopses (seeds) were collected in Poland near Szczecin at the time of natural dispersal in July 2007.
Seeds were dried at room temperature for 7 days and then stored at $-20^{\circ} \mathrm{C}$ until required.

Preparation of smoke-water and isolation of butenolide

Smoke-water was generated by burning Themeda triandra in a standard beekeeper's smoker. The smoke was bubbled through distilled water in a glass jar until the water was yellow in colour. The butenolide (3-methyl-2H-furo[2,3-c] pyran-2-one) was isolated, purified and identified from smoke-water as described by Van Staden et al. (2004).

Incubation of seeds in presence of smoke-water or butenolide

Primary dormant seeds were dehulled (palea and lemma removed). Seeds, 25 in each of three replicates, were incubated in darkness in Petri dishes $(60 \mathrm{~mm})$ on Whatman No. 1 filter paper moistened with $1.5 \mathrm{ml}$ distilled water or butenolide solution. Seeds were incubated in darkness at $15,20,25$ and $30^{\circ} \mathrm{C}$ continuously in the presence of smokewater $(1: 10,000,1: 1,000,1: 100 \mathrm{v} / \mathrm{v})$ or butenolide solution $\left(10^{-10}, 10^{-9}, 10^{-8}, 10^{-7} \mathrm{M}\right)$. All manipulations were performed under a green safe light at $2 \mu \mathrm{mol} \mathrm{m}{ }^{-2} \mathrm{~s}^{-1}$, which had no effect on germination. In all experiments coleorhiza protrusion was used to determine germination.

Preincubation in butenolide or water before transfer to water or butenolide, respectively

Seeds were preincubated at $4^{\circ} \mathrm{C}$ for 6,12 and $24 \mathrm{~h}$ in the presence of $10^{-9}$ and $10^{-8} \mathrm{M}$ or at $20^{\circ} \mathrm{C}$ for $3,6,12$ and $24 \mathrm{~h}$ in presence of $10^{-8} \mathrm{M}$ butenolide. Seeds were then transferred to darkness at $20^{\circ} \mathrm{C}$ on filter paper moistened with distilled water. In a reverse experiment, seeds were preincubated in water for $6,12,24,48,72$ or $120 \mathrm{~h}$ before transfer to $10^{-8} \mathrm{M}$ butenolide.

Incubation of seeds in butenolide and in darkness, continuous or alternating light

Seeds were incubated in water and butenolide $\left(10^{-8} \mathrm{M}\right)$ in darkness and constant light at $8 \mu \mathrm{mol} \mathrm{m}^{-2} \mathrm{~s}^{-1}$ at $20^{\circ} \mathrm{C}$ in the same incubator. In another experiment, seeds were incubated in the same incubator in water or butenolide in darkness or light at $50 \mu \mathrm{mol} \mathrm{m} \mathrm{m}^{-2} \mathrm{~s}^{-1}$ with a $16 \mathrm{~h}$ photoperiod. The number of germinated seeds was scored after 5 days from the start of incubation. Germination in darkness was similar in both incubators.

Flow cytometric analysis

Nuclear DNA contents of radicle and coleorhiza cell tips were determined using flow cytometry. For cell-cycle 
activity determination, 5 replicates of 25 seeds were incubated at $20^{\circ} \mathrm{C}$ for $0,18,24$ and $30 \mathrm{~h}$ in darkness in distilled water or $10^{-8} \mathrm{M}$ butenolide. Radicles (25) with coleorhiza were isolated from imbibed seeds by cutting of the testa and chopping them with a razor blade into $2 \mathrm{ml}$ of a nucleusisolation buffer $(45 \mathrm{mM} \mathrm{MgCl}, 30 \mathrm{mM}$ sodium citrate, $20 \mathrm{mM}$ MOPS, $0.1 \%$ Triton X-100 and $2 \mu \mathrm{g} / \mathrm{ml}$ DAPI) (Galbraith et al. 1983) for $2 \mathrm{~min}$ and incubated for $10 \mathrm{~min}$ at room temperature. After this time the suspension was passed through a $20 \mu \mathrm{m}$ nylon mesh. The DAPI-stained nuclei were analyzed using a Partec PAII flow cytometer (Partec GmbH, Germany). The populations of 2 and $4 \mathrm{C}$ nuclei were measured using 10,000 nuclei.

\section{Seedling growth}

Three replicates of 25 seeds each in Petri dishes, in water, smoke-water $(1: 10,000,1: 1,000 \mathrm{v} / \mathrm{v})$ or butenolide $\left(10^{-10}\right.$, $10^{-9}, 10^{-8} \mathrm{M}$ ) in 3 replicates, were incubated at 15,20 and $25^{\circ} \mathrm{C}$ in darkness. For a control at 20 and $25^{\circ} \mathrm{C}, 6$ replicates of 25 seeds were used. After 5 days five seedlings from each Petri dish were selected and the length of the longest coleoptile and root were measured and fresh seedling weight was determined. Seedling vigor index was calculated as coleoptile length $(\mathrm{cm})+$ longest root $(\mathrm{cm}) \times$ percentage germination.

\section{Statistical analysis}

The average \pm standard deviation (SD) of three independent samples of 25 seeds each are presented. Data were analyzed using one-way and two-way ANOVA (Statistica for Windows ver. 8.0, StatSoft Inc., Tulsa, Oklahoma, USA) to determine statistical differences between mean values $(P<0.05)$. Treatment means were then separated by Duncan's multiple-range test. Similar results were obtained in two independent experiments.

\section{Results}

Germination in presence of smoke-water

and butenolide at various temperatures

Germination of seeds from freshly harvested A. fatua depended on temperature (Fig. 1a, b). At the lowest temperature, $15^{\circ} \mathrm{C}$, about 30 to $40 \%$ of the seeds were able to germinate. However, little germination occurred at temperatures from 20 to $25^{\circ} \mathrm{C}$. Germination percentage at these temperatures was between 20 and $10 \%$, respectively. At $30^{\circ} \mathrm{C}$, seeds did not germinate. The smoke solution was an effective stimulator of germination at temperatures of 15 and $20^{\circ} \mathrm{C}$ (Fig. 1a). Application of smoke solution at a dilution of $1: 1,000$ or $1: 100$ caused complete seed
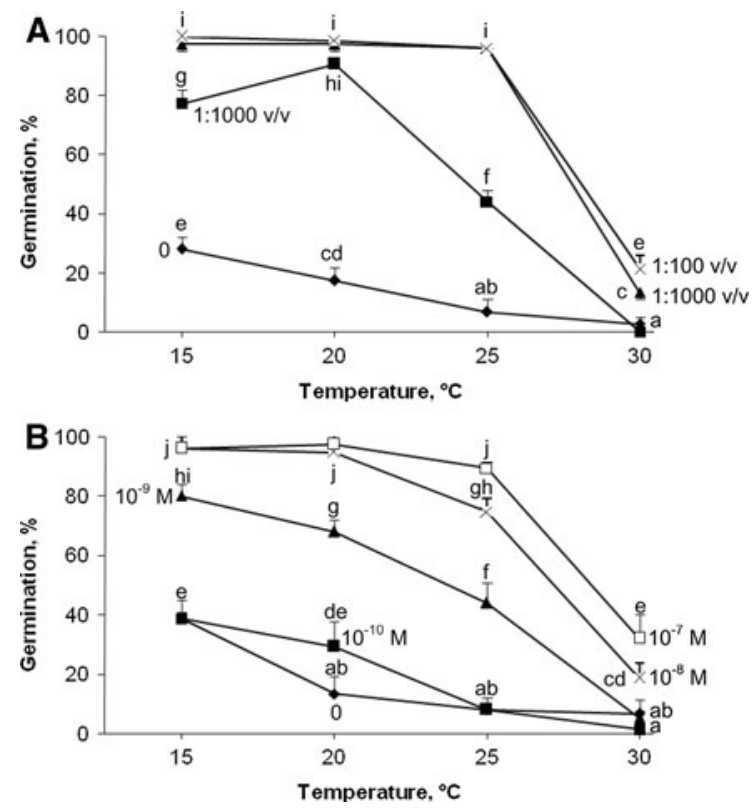

Fig. 1 The effect of smoke-water (a) or butenolide (b) on the germination of A. fatua seeds after 5 days of incubation at 15, 20, 25 and $30^{\circ} \mathrm{C}$. Vertical bars indicate \pm SD. Two-way ANOVA with the Duncan post hoc test was used to determine significant differences. Mean values with different letters $(a-j)$ are significantly different $(P<0.05)$

germination at these temperatures. Smoke at the highest dilution was less active than at higher concentrations especially at $25^{\circ} \mathrm{C}$, although up to $50 \%$ of the seeds still germinated. However, at $30^{\circ} \mathrm{C}$ it was not so effective as at lower temperatures. Only slightly more than $20 \%$ of the seeds germinated, even using the highest smoke-water concentration (1:100). Butenolide also effectively stimulated germination at a range of temperatures from 15 to $30^{\circ} \mathrm{C}$, the effect being dependent on concentration (Fig. 1b). At the lowest concentration used $\left(10^{-10} \mathrm{M}\right)$ germination was only slightly stimulated at $20^{\circ} \mathrm{C}$. However, increasing the concentration of this compound 10 fold $\left(10^{-9} \mathrm{M}\right)$ resulted in $80 \%$ germination at $15^{\circ} \mathrm{C}$. Increasing the temperature decreased germination percentage; 70,50 and $0 \%$ germination at 20,25 and $30^{\circ} \mathrm{C}$, respectively. Butenolide at $10^{-8} \mathrm{M}$ caused complete germination while at 15,20 and $25^{\circ} \mathrm{C}$ germination was high. When the highest concentration of butenolide $\left(10^{-7} \mathrm{M}\right)$ was used all seeds germinated at 15,20 and $25^{\circ} \mathrm{C}$. At $30^{\circ} \mathrm{C}$, the highest temperature used, butenolide at $10^{-8}$ and $10^{-7}$ allowed 40 and $20 \%$ of seeds to germinate, respectively (Fig. 2).

Germination after transfer from butenolide to water and from water to butenolide

Preincubation at $4^{\circ} \mathrm{C}$ for 6 or $12 \mathrm{~h}$ in $10^{-9} \mathrm{M}$ butenolide did not affect germination, but $24 \mathrm{~h}$ of incubation resulted in about $60 \%$ germination. Seeds preincubated for 12 or 
$24 \mathrm{~h}$ at $10^{-8} \mathrm{M}$ butenolide reached about $60 \%$ or $80 \%$ germination, respectively (Fig. 2). To determine the time requirement for treatment with butenolide seeds were preincubated in the presence of this compound $\left(10^{-8} \mathrm{M}\right)$ at $20^{\circ} \mathrm{C}$ for $3,6,12$ or $24 \mathrm{~h}$ and then transferred to water at $20^{\circ} \mathrm{C}$ (Fig. 3a). Pretreatment with butenolide for 3, 6, 12 or $24 \mathrm{~h}$ caused about 45,60 or $95 \%$ of germination, respectively. In a reverse experiment the effect of $10^{-8} \mathrm{M}$ butenolide on germination of seeds preincubated in water was determined (Fig. 3b). The stimulatory effect of butenolide decreased with increasing periods of imbibition in water. Seeds preincubated 6 to $24 \mathrm{~h}$ in water germinated almost completely.

Germination in presence of smoke-water or butenolide in darkness or light

Seeds were incubated in the presence of 1:1,000 smokewater or $10^{-8} \mathrm{M}$ butenolide at $20^{\circ} \mathrm{C}$ in darkness, constant light at $10 \mu \mathrm{mol} \mathrm{m}{ }^{-2} \mathrm{~s}^{-1}$ or $50 \mu \mathrm{mol} \mathrm{m} \mathrm{m}^{-2} \mathrm{~s}^{-1}$ at a $16 \mathrm{~h}$ photoperiod (Fig. 4). Both smoke-water and butenolide as in the previous experiment allowed almost all seeds to germinate in darkness. However, in light smoke-water and butenolide were much less effective. Butenolide caused $60 \%$ germination at $10 \mu \mathrm{mol} \mathrm{m}^{-2} \mathrm{~s}^{-1}$ and $35 \%$ at $50 \mu \mathrm{mol} \mathrm{m} \mathrm{m}^{-2} \mathrm{~s}^{-1}$. Smoke-water increased germination under both light conditions up to about $20 \%$.

Nuclear DNA content in radicle and coleorhiza tips of seeds incubated in smoke-water or butenolide

In dry seeds most of the cells in radicle and coleorhiza tips were arrested in the $G_{1}$ phase of the cell cycle (Fig. 5). Imbibition of dormant seeds in water for up to $30 \mathrm{~h}$, before coleorhiza protrusion in butenolide-treated seeds, did not affect percent of nuclei in $G_{1}, S$ and $G_{2}$. Butenolide

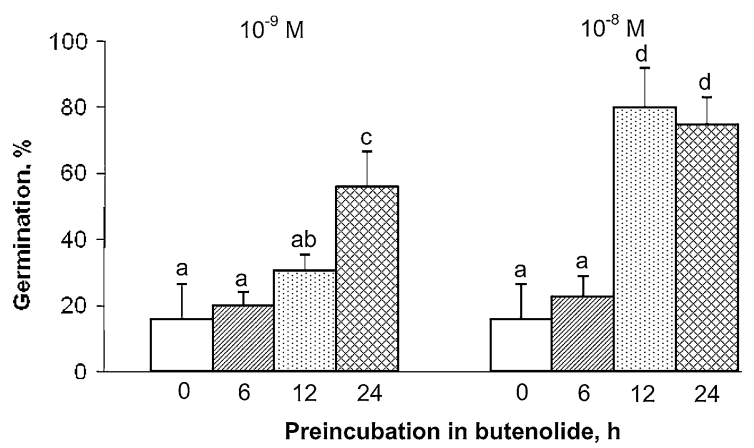

Fig. 2 The germination of $A$. fatua seeds at $20^{\circ} \mathrm{C}$, preincubated at $4^{\circ} \mathrm{C}$ for different periods in the presence of different concentrations of butenolide. Percentage germination did not change up to 7 days. Vertical bars indicate \pm SD. Two-way ANOVA with the Duncan post hoc test was used to determine significant differences. Mean values with different letters $(a-d)$ are significantly different $(P<0.05)$
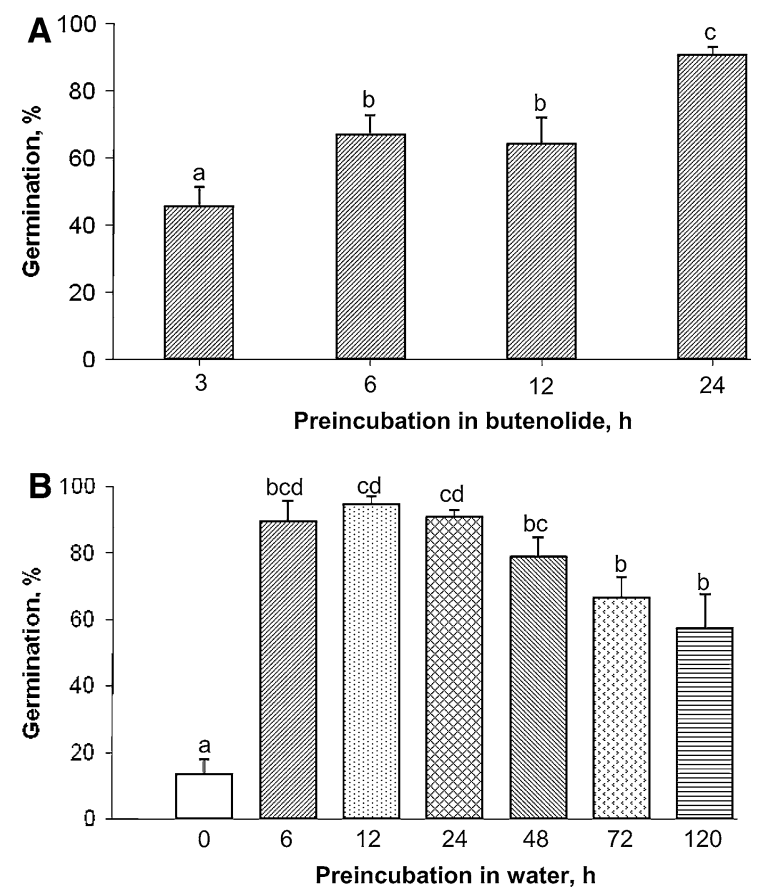

Fig. 3 The germination of $A$. fatua seeds at $20^{\circ} \mathrm{C}$, preincubated at $20^{\circ} \mathrm{C}$ for different periods in the presence of $10^{-8} \mathrm{M}$ butenolide (a) or preincubated in water before transfer to butenolide (b). Percentage germination did not change up to 7 days. Vertical bars indicate \pm SD. Two-way ANOVA with the Duncan post hoc test was used to determine significant differences. Mean values with different letters $(a-d)$ are significantly different $(P<0.05)$

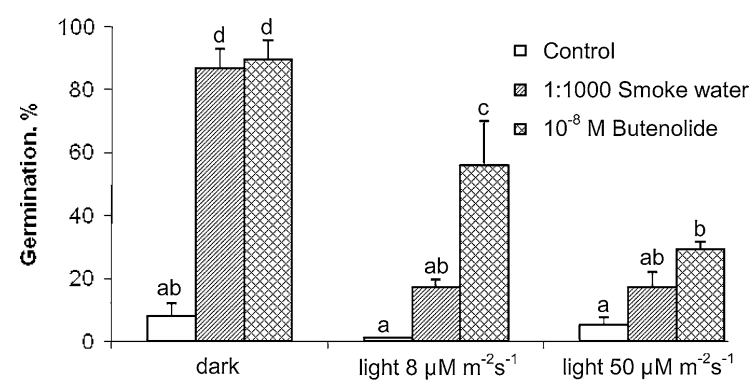

Fig. 4 The effect of smoke-water and butenolide on the germination of A. fatua seeds at $20^{\circ} \mathrm{C}$ in the dark or light. Vertical bars indicate \pm SD. Two-way ANOVA with the Duncan post hoc test was used to determine significant differences. Mean values with different letters $(a-d)$ are significantly different $(P<0.05)$

decreased the number of nuclei in $\mathrm{G}_{1}$ about two-fold and increased it by a factor of 6 and 3 in phase $S$ and $G_{2}$, respectively. Imbibition in water up to $30 \mathrm{~h}$ did not influence the $G_{2} / G_{1}$ ratio. Butenolide only increased the number of nuclei five fold and the $\mathrm{G}_{2} / \mathrm{G}_{1}$ ratio prior to coleorhiza protrusion after $30 \mathrm{~h}$ of imbibition.

Effect of smoke or butenolide on growth of seedlings

Five days after placing seeds in water, smoke-water solutions or butenolide at various concentrations, growth of the 
coleoptile, root length, fresh weight and vigor index were estimated (Fig. 6). Smoke and butenolide only slightly increased coleoptile growth at $15^{\circ} \mathrm{C}$. At 20 and $25^{\circ} \mathrm{C}$ both treatments markedly increased coleoptile and root length. Smoke-water and butenolide increased the vigor index at all temperatures. The best effect was observed at 20 and $25^{\circ} \mathrm{C}$ when the highest concentration of smoke-water or butenolide were used and the vigor index increased seven fold.

\section{Discussion}

Freshly harvested seeds of A. fatua were considered as being primary dormant as they germinated poorly at temperatures from 20 to $30^{\circ} \mathrm{C}$, reaching values less than $20 \%$. This dormancy was completely released at temperatures below $30^{\circ} \mathrm{C}$ by smoke-water. Previous results showed that smoke-water caused total germination of partially dormant A. fatua seeds (Adkins and Peters 2001; Kępczyński et al. 2006). Butenolide was a very active dormancy breaking factor at very low concentrations $\left(10^{-8} \mathrm{M}\right)$ and could remove completely or partially deep dormancy in seeds at $15-25^{\circ} \mathrm{C}$. Fully dormant seeds of $A$. fatua were more sensitive to butenolide than partially dormant seeds from the United Kingdom (Daws et al. 2007) and Australia (Stevens et al. 2007). Similar effects of smoke-water and butenolide on seed germination were observed in
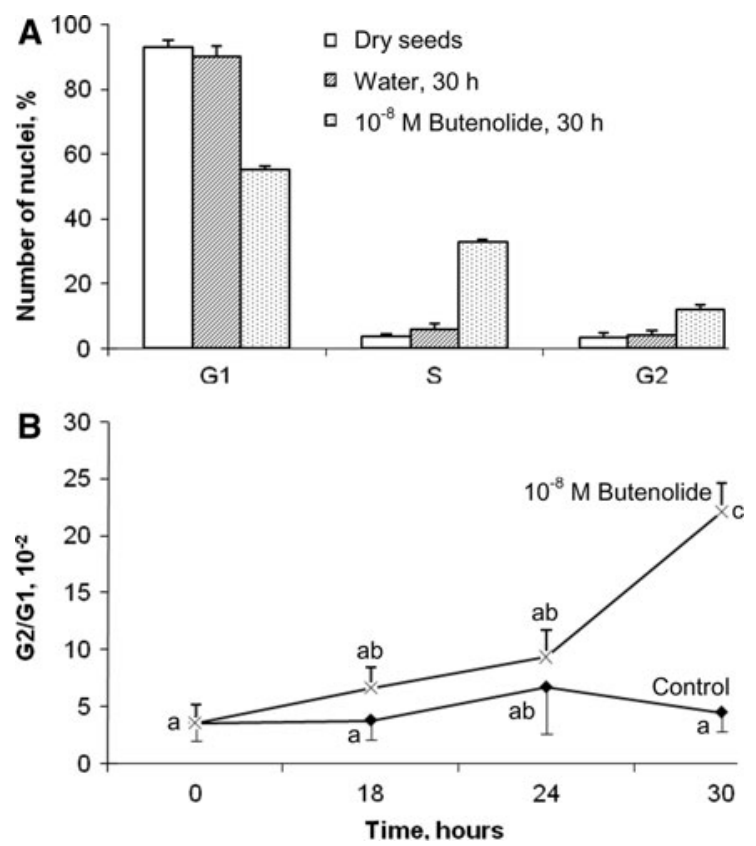

Fig. 5 The effect of butenolide on the nuclear DNA content (a) and G2/G1 ratio (b) of A. fatua coleorhiza tip cells. Vertical bars indicate \pm SD. Two-way ANOVA with the Duncan post hoc test was used to determine significant differences. Mean values with different letters $(a-c)$ are significantly different $(P<0.05)$ experiments with Asteraceae (Merritt et al. 2006) and some agricultural plants (Daws et al. 2007; Stevens et al. 2007). This suggests that butenolide, isolated from plant or cellulose-derived smoke (Van Staden et al. 2004; Flematti et al. 2004) is responsible for the smoke effect on seeds of several plant species and also on seeds of the weed A. fatua. Seeds of some species may respond differently to butenolide and smoke, since smoke contains, apart from butenolide, many other compounds (Light et al. 2009). The comparative effects of smoke and butenolide on seed germination at various temperatures indicates that sensitivity to these stimulants decreased with increasing temperature. Dormancy in seeds can also be broken by butenolide application for 12 or $24 \mathrm{~h}$ at $4^{\circ} \mathrm{C}$. Likewise, preincubation for 6 to $12 \mathrm{~h}$ or $24 \mathrm{~h}$ at $20^{\circ} \mathrm{C}$ removed dormancy in more than $60 \%$ or all seeds. These results indicate that continuous presence of this compound is not necessary for releasing dormancy. A previous study showed that soaking of non-dormant tomato seeds in butenolide solution for $24 \mathrm{~h}$ was sufficient to improve germination and vigor (Jain and Van Staden 2007). Results obtained with A. fatua seeds allows us to suggest that smoke produced under natural conditions may affect germination when available for short durations at both low or higher temperatures. Prolonged preincubation in water before transfer to butenolide reduced its stimulatory effect, thus it decreased sensitivity of seeds to this compound suggesting that imbibed seeds in the soil probably may have limited sensitivity to smoke. Stimulatory effects of smoke and butenolide were light dependent, with constant light at $10 \mu \mathrm{mol} \mathrm{m} \mathrm{m}^{-2} \mathrm{~s}^{-1}$ and a $16 \mathrm{~h}$ photoperiod at $50 \mu \mathrm{mol} \mathrm{m} \mathrm{m}^{-2} \mathrm{~s}^{-1}$ decreasing sensitivity to smoke and butenolide. Butenolide was more effective than smoke as a dormancy breaking factor under constant light conditions and photoperiod. It might be associated with interaction of compound(s) from smoke with light. Both smoke and butenolide were able to partially or fully replace the light requirement in lettuce (Van Staden et al. 2004) and Australian Asteraceae seeds (Merritt et al. 2006).

Dormant A. fatua embryos are arrested in $\mathrm{G}_{1}$. The quiescent embryos of some species have cells arrested in $\mathrm{G}_{0}$ or $\mathrm{G}_{1}$ and others at $\mathrm{S}$ or $\mathrm{G}_{2}$ (Groot et al. 1997). Replication of DNA in dormant A. fatua seeds was blocked since the number of nuclei in phase $\mathrm{G}_{2}$ did not increase. Breaking dormancy by butenolide is associated with an increasing number of nuclei at $S$ and $G_{2}$ and an increasing ratio $G_{2} / G_{1}$ just before coleorhiza protrusion. Butenolide also enhanced both germination and percentage of number of nuclei in non-dormant tomato seeds (Jain and Van Staden 2007).

Smoke and butenolide improved seedling establishment particularly at 20 and $25^{\circ} \mathrm{C}$. The stimulatory effect on roots and coleoptiles increased with increasing temperature. Both smoke and butenolide effectively increased seedling 
Fig. 6 The effect of smokewater or butenolide on coleoptyle $(\mathbf{a}, \mathbf{b})$, root length $(\mathbf{c}, \mathbf{d})$, fresh weight $(\mathbf{e}, \mathbf{f})$ and vigor index (g, h) of A. fatua seedlings. Seedlings were measured after 5 days from beginning of experiment. Vertical bars indicate $\pm \mathrm{SD}$. One-way ANOVA with the Duncan post hoc test used to determine significant differences. Columns with an asterisk are significantly different from the control $(P<0.05)$
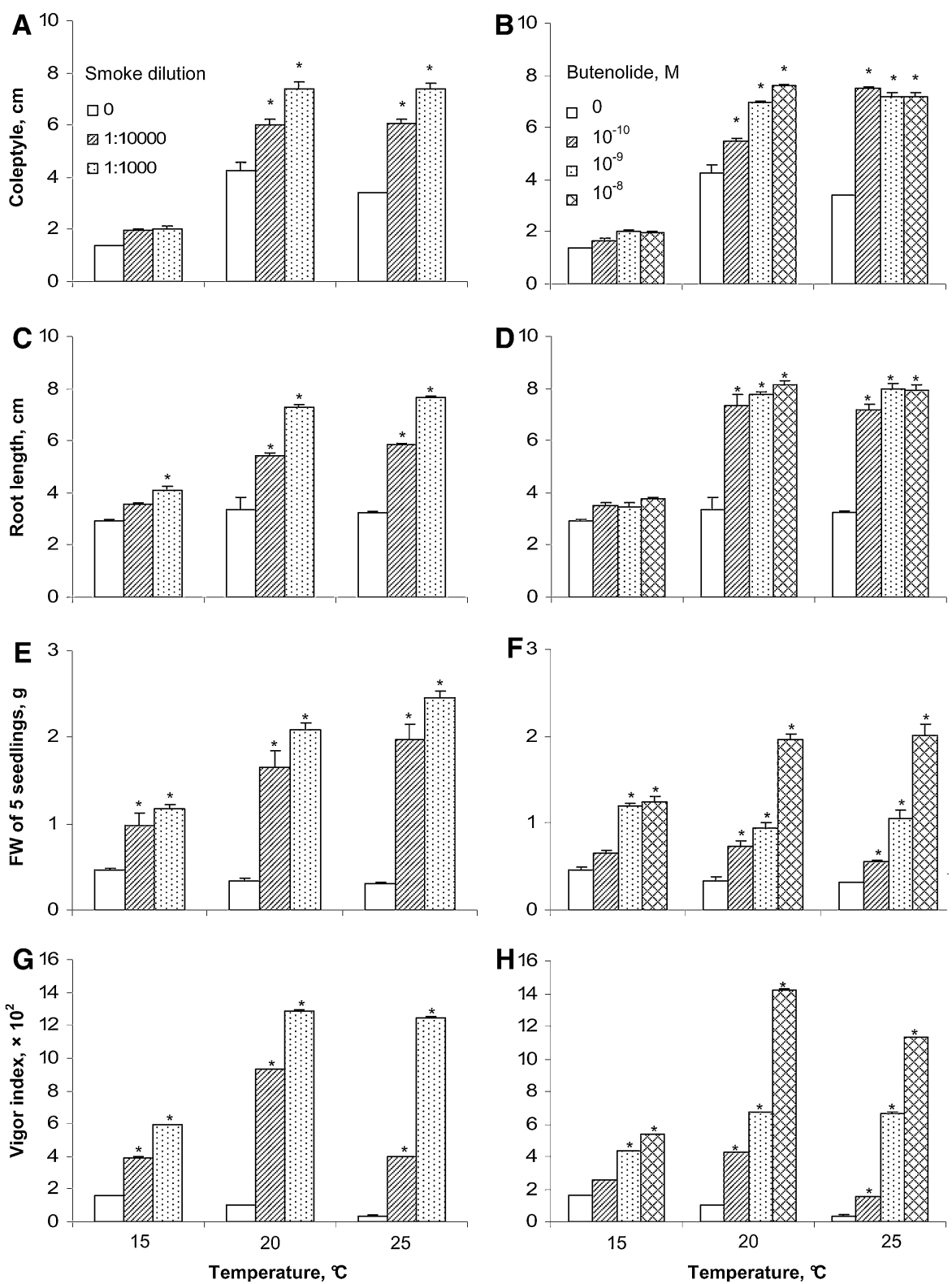

fresh weight and the vigor index at all temperatures. Improved shoot and root growth and seedling vigor due to smoke or butenolide treatment were also observed in rice (Kulkarni et al. 2006), tomato (Jain and Van Staden 2006) and Acacia (Kulkarni et al. 2007).

These results indicate that the effect of smoke on breaking deep primary dormancy of A. fatua seeds in darkness at temperatures from 15 to $25^{\circ} \mathrm{C}$ is associated with the butenolide present in smoke. This compound can be used as a dormancy breaking agent at low concentrations such as $10^{-8} \mathrm{M}$ continuously or for only 12 or $24 \mathrm{~h}$ at $4^{\circ} \mathrm{C}$ or $20^{\circ} \mathrm{C}$. Activity of butenolide was lower in light than in darkness. Breaking dormancy of A. fatua seeds by butenolide involves cell-cycle activation. Effect of smoke or butenolide applied continuously during seed incubation in the dark was manifested in increased coleoptile growth, root growth and seedling vigor.

Acknowledgments The study was supported by the Ministry of Science and Higher Education of Poland grant NN310151935.

Open Access This article is distributed under the terms of the Creative Commons Attribution Noncommercial License which permits any noncommercial use, distribution, and reproduction in any medium, provided the original author(s) and source are credited.

\section{References}

Adkins SW, Ross JD (1981) Studies in wild oat seed dormancy. I. The role of ethylene in dormancy breakage and germination of wild oat seeds (Avena fatua L.). Plant Physiol 67:358-362 
Adkins SW, Loewen M, Symons SJ (1986) Variations within pure lines of wild oat (Avena fatua $\mathrm{L}$.) in relation to degree of primary dormancy. Weed Sci 34:859-864

Adkins SW, Peters NCB (2001) Smoke derived from burnt vegetation stimulates germination of arable weeds. Seed Sci Res 11:213-222

Brown NAC (1993) Promotion of germination of fynbos seeds by plant-derived smoke. New Phytol 123:575-583

Brown NAC, Van Staden J (1997) Smoke as a germination cue: a review. Plant Growth Regul 22:115-124

Daws MI, Davies J, Pritchard HW, Brown NAC, Van Staden J (2007) Butenolide from plant-derived smoke enhances germination and seedling growth of arable weed species. Plant Growth Regul 51:73-82

De Lange JH, Boucher C (1990) Autecological studies on Audouinia capitata (Bruniaceae). I. Plant-derived smoke as a seed germination cue. S Afr J Bot 56:700-703

Flematti GR, Ghisalberti EL, Dixon KW, Trengove RD (2004) A compound from smoke that promotes seed germination. Science 305:977

Foley ME (1994) Temperature and water status of seed affect afterripening in wild oat (Avena fatua). Weed Sci 42:200-204

Galbraith DW, Harkins KR, Maddox JM, Ayres NM, Sharma DP, Firoozabady E (1983) Rapid flow cytometric analysis of cell cycle in intact plant tissues. Science 220:1049-1051

Groot SPC, de Castro RD, Liu Y, Bino RJ (1997) Cell cycle analysis in dormant and germinating tomato seeds. In: Ellis RH, Black M, Murdoch AJ, Hong TD (eds) Basic and applied aspects of seed biology. Kluwer Academic, Dordrecht, pp 395-402

Hilton JR, Bitterli CJ (1983) The influence of light on the germination of Avena fatua L. (wild oat) seed and its ecological significance. New Phytol 95:325-333

Jain N, Van Staden J (2006) A smoke-derived butenolide improves early growth of tomato seedlings. Plant Growth Regul 50:139-148

Jain N, Van Staden J (2007) The potential of the smoke-derived compound 3-methyl-2H-furo[2, 3-c]pyran-2-one as a priming agent for tomato seeds. Seed Sci Res 17:175-181
Kępczyński J, Białecka B, Light ME, Van Staden J (2006) Regulation of Avena fatua seed germination by smoke solution, gibberellin $\mathrm{A}_{3}$ and ethylene. Plant Growth Regul 49:9-16

Kulkarni MG, Sparg SG, Light ME, Van Staden J (2006) Stimulation of rice (Oryza sativa L.) seedling vigour by smoke-water and butenolide. J Agron Crop Sci 192:395-398

Kulkarni MG, Sparg SG, Van Staden J (2007) Germination and postgermination response of Acacia seeds to smoke-water and butenolide, a smoke-derived compound. J Arid Environ 69: 177-187

Light ME, Daws MI, Van Staden J (2009) Smoke-derived butenolide: towards understanding its biological effects. S Afr J Bot 75: $1-7$

Maga JA (1988) Smoke in food processing. CRC Press, Boca Raton. ISBN: 0-8493-5155-3, pp 1-160

Merritt DJ, Kristiansen M, Flematti GR, Turner SR, Ghisalberti EL, Trengove RD, Dixon KW (2006) Effects of a butenolide present in smoke on light-mediated germination of Australian Asteraceae. Seed Sci Res 16:29-35

Naylor JM (1983) Studies on the genetic control of some physiological processes in seeds. Can J Bot 61:3561-3567

Naylor JM, Fedec P (1978) Dormancy studies in seed of Avena fatua. 8. Genetic diversity affecting responses to temperature. Can J Bot 66:2224-2229

Stevens JC, Merritt DJ, Flematti GR, Ghisalberti EL, Dixon KW (2007) Seed germination of agricultural weeds is promoted by the butenolide 3-methyl-2H-furo[2, 3-c]pyran-2-one under laboratory and field conditions. Plant Soil 298:113-124

Van Staden J, Jäger AK, Light ME, Burger BV (2004) Isolation of the major germination cue from plant-derived smoke. S Afr J Bot 70:654-659

Van Staden J, Sparg SG, Kulkarni MG, Light ME (2006) Postgermination effects of the smoke-derived compound 3-methyl$2 \mathrm{H}$-furo[2, 3-c]pyran-2-one, and its potential as a preconditioning agent. Field Crops Res 98:98-105 